\title{
Effects of Strain and Skip-a-day Feed Restriction on Carcass Characteristics of Broiler Chickens at Finisher Stage
}

\author{
Akinyemi Felicia Omolola, Olawumi Simeon Olutoye* \\ Department of Animal Science, Ekiti State University, P. M. B. 5363, Ado-Ekiti, Nigeria
}

\section{*Corresponding Author}

Olawumi Simeon Olutoye

\author{
Article History \\ Received: 12.06 .2020 \\ Accepted: 19.06.2020 \\ Published: 12.07 .2020
}

\begin{abstract}
The present study was undertaken to investigate the effects of strain and feed restriction on live weight and carcass characteristics of broiler chickens. Feed restriction is a management tool designed to reduce the amount of feed consumed by broilers to produce more meat without jeopardizing their health condition. The strains of broilers reared are Arbor Acre, Hubbard and Marshall. The four treatments are: A- full feeding (control), B- $5^{\text {th }}$ week feed restricted, C- $6^{\text {th }}$ week feed restricted and D- $7^{\text {th }}$ week feed restricted groups. After each feed restriction regime the birds were restored to full feeding until the termination of the experiment on the $56^{\text {th }}$ day. Analyzed results showed that there was no significant ( $>0.05$ ) effect of strain on live weight, bled weight, dressed weight, eviscerated weight, breast weight, back weight, thigh, drumstick, wing weight, head, heart, liver, proventriculus, intestine weight, spleen, lung + trachea, vent and shank. Arbor Acre, Hubbard and Marshal strains of broiler recorded similar mean values regardless of the treatment imposed on them. Therefore, any of the strains of broiler chickens can be reared for meat production and revenue generation. In addition, there was significant $(\mathrm{p}<0.01)$ effect of feed restriction regimes on live weight of broiler chickens and carcass traits except back, thigh and wing muscle weights. The $5^{\text {th }}$ week restricted birds recorded superior mean values than $6^{\text {th }}$ and $7^{\text {th }}$ week restricted birds in some of the traits measured. It is therefore suggested that feed restriction be carried out at younger age, say $5^{\text {th }}$ week, for farmers to derive maximum benefits from the concept. Any other time during finisher stage may be counterproductive.
\end{abstract}

Keywords: Strain, broiler, live weight, Arbor Acre, Hubbard, Marshall.

\section{INTRODUCTION}

Poultry producers have over the years selected vigorously for lines of chicken that grow faster, convert feed more efficiently to produce more meat desirable and acceptable by all age groups since there is no taboos to its production and consumption in any society. Nevertheless, it has become apparent over these years that a significant percentage of the improved body weight (as a result of overeating) in broilers consists of fatty carcass which represents economic loss to the producers [1].

Due to the fact that meat consumers are becoming increasingly conscious of the health implications of high dietary fat, there is an increasing desire to produce meat products which are low in fat. Excessive fat does not only reduce carcass yield and feed-efficiency but also causes difficulties in processing leading rejection of the meat by consumers. To reduce incidences of rejection at processing plant as a result of fat deposits, feed restriction regimes had been employed [2-4].

In previous study, Saleh et al., [5] reported efficient feed conversion and reduced mortality with feed restricted birds, while Zhong et al., [6] observed reduced carcass and abdominal fat content at market age in feed-restricted birds than in birds fed ad libitum. Other workers however, indicated that even though feed-restricted birds had lower fat content, their feed efficiency was similar to that of birds fed ad libitum [7, 8]. However, Fontana et al., [9] and Saleh et al., [5] observed that feed restriction had no effect on carcass and abdominal fat content.

Copyright @ 2020: This is an open-access article distributed under the terms of the Creative Commons Attribution license which permits unrestricted use, distribution, and reproduction in any medium for non commercial use (NonCommercial, or CC-BY-NC) provided the original author and source are credited. 
In addition, Azarnik et al., [10] and Fasuyi et al., [11] reported that some carcass traits such as bled weight, breast muscle and thigh weight were significantly affected by feed restriction. Also, Olawumi et al., [12] observed similar live weight and other carcass characteristics in different strains of broilers.

In an attempt to further explore the advantages of feed restriction, this study was conducted to examine the effects of skip-a-day feeding during the finisher period, followed by full-feeding to market age on carcass characteristics in some strains of commercial broiler chickens.

\section{Materials ANd Methods}

The study was carried out at Poultry Unit of the Teaching and Research Farm, Faculty of Agricultural Sciences, Ekiti State University, Ado-Ekiti, Nigeria. Ado-Ekiti is situated entirely within the tropics. It is located between longitudes $40^{\circ} 51^{\prime}$ and $50^{\circ} 451^{\prime}$ east of the Greenwich meridian and latitudes $70^{\circ} 151^{\prime}$ and $80^{\circ} 511^{\prime}$ north of the Equator.

Two hundred and eighty eight (288) day old broiler chicks comprising of 96 chicks each of Arbor Acre, Hubbard and Marshal were purchased from reputable hatcheries. The chicks were distributed randomly at the starter phase into 12 pens per strain, that is, four treatments with three replicates per treatment and 8 chicks per replicate. The experiment was a completely randomized design arranged in a $3 \times 4$ factorial design.

The four treatments are: A- full feeding, B-feed restricted $\left(5^{\text {th }}\right.$ week, $29-35^{\text {th }}$ day), C- feed restricted $\left(6^{\text {th }}\right.$ week, $36-42^{\text {nd }}$ day) and D- feed restricted group ( $7^{\text {th }}$ week, 43-49 day). After each feed restriction regime the birds were restored to full feeding until the termination of the experiment on the $56^{\text {th }}$ day. Commercial broiler starter feed containing $22 \% \mathrm{CP}$ and $3000 \mathrm{kcal} / \mathrm{kg}$ were given from 1 - 28 days while broiler finisher feed having $21 \% \mathrm{CP}$ and $3100 \mathrm{kcal} / \mathrm{kg}$ were offered from 29 to 56 days. Water was given ad libitum.

At the end of the 56 days trial, the birds were starved overnight and two birds per replicate were randomly selected, weighed, slaughtered, dressed and eviscerated. Data on live weight, slaughter weight, dressed weight and eviscerated weight, breast, back, drumstick, thigh, neck, head weights were obtained. Also, the weights of the viscera organs: liver, heart, proventriculus, gizzard and intestine were also obtained and recorded. The equipments used for weighing these parameters included table scale (Five Goats ${ }^{\circledR}$ ) and sensitive weighing balance (Mx Rady 300, Winteck Nig., Ltd).

\section{Statistical Analysis}

Data obtained were subjected to analysis of variance (ANOVA) using SAS [13]. Duncan's Multiple Range test was used to separate differences among the means at $(\mathrm{P}=0.05)$.

The appropriate statistical model used was:

$$
\mathrm{Y}_{\mathrm{ijk}}=\mu+\mathrm{G}_{\mathrm{i}}+\mathrm{R}_{\mathrm{j}}+(\mathrm{GR})_{\mathrm{ij}}+\varepsilon_{\mathrm{ijk}}
$$

Where,

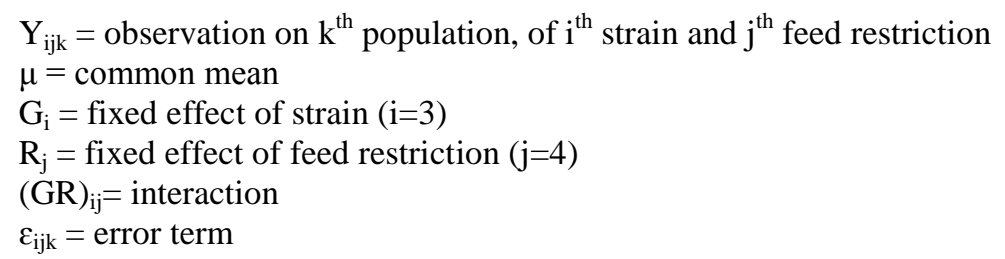

\section{RESUlTS AND DisCUSSION}

Table-1 presents the effect of strain on live weight and carcass characteristics. The result showed that there was no significant $(\mathrm{p}>0.05)$ effect of strain on live weight, bled weight, dressed weight, eviscerated weight, breast weight, back weight, thigh, drumstick, wing weight, head, heart, liver, proventriculus, intestine weight, spleen, lung + trachea, vent and shank. Arbor Acre, Hubbard and Marshal strains of broiler recorded similar mean values regardless of the treatment imposed on them. It means that the three strains have similar genetic background, utilized the feed efficiently and converted same to meat accordingly. Therefore, any of the strains of broiler chickens can be reared for meat production and revenue generation.

The obtained result was in agreement with the previous findings $[11,12,14]$. It is however, contrary to the findings of Chukwuka et al., [15] who reported that there were significant differences among carcass characteristics of different strains of broilers. The difference between earlier studies and the present result may be due to the type or strain of broiler used, geographical location, treatment applied and age of slaughter of experimental birds. 
Table $2 \& 3$ shows the effect of feed restriction regimes on broiler chickens live weight and carcass characteristics. The result showed that there was significant $(\mathrm{p}<0.01)$ effect of feed restriction regimes on live weight of broiler chickens. Birds on control (ad libitum) and $5^{\text {th }}$ week feed restriction recorded the highest mean value while birds on sixth week and seventh week feed restriction showed the lowest but similar ( $>0.05)$ values of live weight. For bled weight and dressed weight, birds on control (ad libitum) recorded superior values while birds on sixth week feed restriction recorded the lowest mean values. With eviscerated weight, there was significant $(p<0.01)$ effect of feed restriction on the trait. Birds on control (ad libitum) showed superiority to others, while birds on seventh week feed restriction had intermediate value of eviscerated weight. However, birds on fifth and sixth week feed restriction had the least values of this trait at 8 weeks.

In the same vein, breast weight was significantly $(\mathrm{p}<0.01)$ affected by feed restriction. Birds on the control $(\mathrm{ad}$ libitum) had the highest mean value, while birds on seventh week feed restriction recorded the lowest mean value of the trait. Also, there was significant $(\mathrm{p}<0.01)$ effect of feed restriction on drum stick, as birds on control and sixth week feed restriction recorded highest mean values. The birds on seventh week feed restriction showed the lowest value of drumstick. There was significant effect of feed restriction on the head. Birds on control (ad libitum) and sixth week feed restriction showed superiority to others, while birds on the seventh week feed restriction recorded the lowest mean value of head at age 8 weeks.

However, feed restriction had no effect on back weight, thigh weight, wing weight, heart, liver, proventriculus, intestine weight, spleen, lung + trachea, vent, shank, gizzard and neck.

With regards to feed restriction, birds fed ad libitum recorded the highest mean value followed by $5^{\text {th }}$ week feed restriction while birds on $6^{\text {th }}$ week and $7^{\text {th }}$ week feed restriction showed the least values of live weight regardless of the strain of broilers. This could be attributed to the fact that the birds in this group had unrestricted access to feed and water, thereby efficiently converted the feed to flesh. At the end of eight weeks, the birds on $5^{\text {th }}$ week feed restriction performed better than $6^{\text {th }}$ and $7^{\text {th }}$ week feed restriction in terms of live weight. This could be attributed to the fact the $5^{\text {th }}$ week feed restriction birds adjusted faster and better than birds on $6^{\text {th }}$ and $7^{\text {th }}$ week feed restriction. The live weight of birds placed on $5^{\text {th }}$ week feed restriction are similar to birds fed ad libitum. This indicated the ability of $5^{\text {th }}$ week feed restriction birds to catch-up with control birds. The results were in agreement with the findings of Khetani et al., [16] and Olawumi [17], who observed catch-up growth in live weight of broilers upon refeeding after feed restriction. However, birds on the control (ad libitum) had the highest value of breast weight; while birds on $7^{\text {th }}$ week feed restriction recorded the least mean value of the trait. This contradicts the report of Azarnik et al., [10] who reported that there is an increase in breast weight after a feed restriction regime, but agree with Fasuyi et al., [11] who found that some carcass traits (such as bled weight, breast muscle and thigh weight) were affected by feed restriction. As regards back weight and thigh weight, the traits were not significantly affected by feed restriction regimes. Superior values in drumstick were recorded by birds on control and $6^{\text {th }}$ week feed restriction. In general, both the weight and proportion of carcass cuts were significantly affected by feed restriction programme.

Table-1: Least squares means showing the effect of strain on live weight and carcass characteristics and giblets of broiler chickens

\begin{tabular}{|l|l|l|l|}
\hline Traits (g) & ARBOR ACRE & HUBBARD & MARSHALL \\
\hline Live weight & $2060.08 \pm 31.14$ & $2024.33 \pm 31.14$ & $2002.00 \pm 31.14$ \\
\hline Bled weight & $1987.92 \pm 38.52$ & $1923.58 \pm 38.52$ & $1963.00 \pm 38.52$ \\
\hline Dressed weight & $1881.42 \pm 39.54$ & $1836.00 \pm 39.54$ & $1865.92 \pm 39.54$ \\
\hline Eviscerated weight & $1581.08 \pm 34.23$ & $1535.08 \pm 34.23$ & $1554.25 \pm 34.23$ \\
\hline Breast weight & $398.00 \pm 16.37$ & $382.92 \pm 16.37$ & $389.08 \pm 16.37$ \\
\hline Back weight & $172.42 \pm 13.73$ & $154.25 \pm 13.73$ & $167.67 \pm 13.73$ \\
\hline Thigh & $110.00 \pm 4.62$ & $103.42 \pm 4.62$ & $100.25 \pm 4.62$ \\
\hline Drum stick & $110.83 \pm 4.01$ & $99.83 \pm 4.01$ & $105.42 \pm 4.01$ \\
\hline Wing weight & $84.75 \pm 2.94$ & $84.58 \pm 2.94$ & $81.33 \pm 2.94$ \\
\hline Head & $52.25 \pm 1.48$ & $52.58 \pm 1.48$ & $55.42 \pm 1.48$ \\
\hline Heart & $8.25 \pm 0.48$ & $7.92 \pm 0.48$ & $8.08 \pm 0.48$ \\
\hline Liver & $38.83 \pm 1.44$ & $37.50 \pm 1.44$ & $39.42 \pm 1.44$ \\
\hline Proventriculus & $9.25 \pm 0.55$ & $8.92 \pm 0.55$ & $8.67 \pm 0.55$ \\
\hline Intestines weight & $117.33 \pm 6.29$ & $124.08 \pm 6.29$ & $122.42 \pm 6.29$ \\
\hline Spleen & $1.50 \pm 0.19$ & $1.58 \pm 0.19$ & $1.17 \pm 0.19$ \\
\hline Lung + Trachea & $8.50 \pm 0.86$ & $10.58 \pm 0.86$ & $10.67 \pm 0.86$ \\
\hline Vent & $19.17 \pm 1.10$ & $19.58 \pm 1.10$ & $19.83 \pm 1.10$ \\
\hline Shank & $38.75 \pm 1.08$ & $40.00 \pm 1.08$ & $40.50 \pm 1.08$ \\
\hline Gizzard & $46.33 \pm 3.20$ & $41.58 \pm 3.20$ & $46.25 \pm 3.20$ \\
\hline Neck & $116.92 \pm 3.92$ & $113.50 \pm 3.92$ & $106.58 \pm 3.92$ \\
\hline
\end{tabular}

Note: means with no superscripts along rows are not significantly different $(\mathrm{p}>0.05)$ 
Table-2: Least squares means showing the effect of feed restriction on broilers' live weight and carcass characteristics

\begin{tabular}{|l|l|l|l|l|}
\hline Parameter (g) & Control (ad libitum) & $\begin{array}{l}\text { Fifth week } \\
\text { feed restriction }\end{array}$ & $\begin{array}{l}\text { Sixth week } \\
\text { feed restriction }\end{array}$ & $\begin{array}{l}\text { Seventh week } \\
\text { feed restriction }\end{array}$ \\
\hline Live weight & $2128.89^{\mathrm{a}} \pm 35.96$ & $2021.11^{\mathrm{ab}} \pm 35.96$ & $1962.11^{\mathrm{b}} \pm 35.96$ & $2003.11^{\mathrm{b}} \pm 35.96$ \\
\hline Bled weight & $2071.67^{\mathrm{a}} \pm 44.48$ & $1953.56^{\mathrm{ab}} \pm 44.48$ & $1869.67^{\mathrm{b}} \pm 44.48$ & $1937.78^{\mathrm{ab}} \pm 44.48$ \\
\hline Dressed weight & $1964.44^{\mathrm{a}} \pm 45.65$ & $1862.11^{\mathrm{ab}} \pm 45.65$ & $1777.00^{\mathrm{b}} \pm 45.65$ & $1840.89^{\mathrm{ab}} \pm 45.65$ \\
\hline Eviscerated weight & $1669.78^{\mathrm{a}} \pm 39.52$ & $1527.33^{\mathrm{b}} \pm 39.52$ & $1462.67^{\mathrm{b}} \pm 39.52$ & $1567.44^{\mathrm{ab}} \pm 39.52$ \\
\hline Breast weight & $426.67^{\mathrm{a}} \pm 18.91$ & $381.56^{\mathrm{ab}} \pm 18.91$ & $380.22^{\mathrm{ab}} \pm 18.91$ & $371.56^{\mathrm{b}} \pm 18.91$ \\
\hline Back weight & $191.11 \pm 15.85$ & $150.33 \pm 15.85$ & $170.00 \pm 15.85$ & $147.67 \pm 15.85$ \\
\hline Thigh & $107.56 \pm 5.34$ & $108.22 \pm 5.34$ & $96.78 \pm 5.34$ & $105.67 \pm 5.34$ \\
\hline Drum stick & $111.33^{\mathrm{a}} \pm 4.64$ & $102.78^{\mathrm{ab}} \pm 4.64$ & $111.44^{\mathrm{a}} \pm 4.64$ & $95.89^{\mathrm{b}} \pm 4.64$ \\
\hline Wing weight & $87.78 \pm 3.39$ & $82.00 \pm 3.39$ & $84.89 \pm 3.39$ & $79.56 \pm 3.39$ \\
\hline Head & $55.56^{\mathrm{a}} \pm 1.71$ & $53.44^{\mathrm{ab}} \pm 1.71$ & $55.44^{\mathrm{a}} \pm 1.71$ & $49.22^{\mathrm{b}} \pm 1.71$ \\
\hline
\end{tabular}

Note: ab means with different superscripts along rows are significantly different $(\mathrm{p}<0.01)$

Table-3: Least squares means showing the effect of feed restriction on broilers' Giblets

\begin{tabular}{|l|l|l|l|l|}
\hline Traits (g) & Control (ad libitum) & $\begin{array}{l}\text { Fifth week } \\
\text { feed restriction }\end{array}$ & $\begin{array}{l}\text { Sixth week } \\
\text { feed restriction }\end{array}$ & $\begin{array}{l}\text { Seventh week } \\
\text { feed restriction }\end{array}$ \\
\hline Heart & $8.00 \pm 0.56$ & $7.78 \pm 0.56$ & $8.00 \pm 0.56$ & $8.56 \pm 0.56$ \\
\hline Liver & $37.00 \pm 1.67$ & $40.22 \pm 1.67$ & $37.56 \pm 1.67$ & $39.56 \pm 1.67$ \\
\hline Proventriculus & $8.44 \pm 0.63$ & $8.56 \pm 0.63$ & $8.89 \pm 0.63$ & $9.89 \pm 0.63$ \\
\hline Intestines weight & $116.33 \pm 7.26$ & $118.78 \pm 7.26$ & $134.78 \pm 7.26$ & $115.22 \pm 7.26$ \\
\hline Spleen & $1.44 \pm 0.22$ & $1.33 \pm 0.22$ & $1.44 \pm 0.22$ & $1.44 \pm 0.22$ \\
\hline Lung + Trachea & $9.11 \pm 1.00$ & $11.33 \pm 1.00$ & $10.00 \pm 1.00$ & $9.22 \pm 1.00$ \\
\hline Vent & $21.67 \pm 1.27$ & $18.89 \pm 1.27$ & $19.00 \pm 1.27$ & $18.56 \pm 1.27$ \\
\hline Shank & $41.00 \pm 1.25$ & $41.11 \pm 1.25$ & $38.33 \pm 1.25$ & $38.56 \pm 1.25$ \\
\hline Gizzard & $51.00 \pm 3.69$ & $41.89 \pm 3.69$ & $43.00 \pm 3.690$ & $43.00 \pm 3.69$ \\
\hline Neck & $117.22 \pm 4.53$ & $112.33 \pm 4.53$ & $109.67 \pm 4.53$ & $110.11 \pm 4.53$ \\
\hline
\end{tabular}

Note: means with no superscripts along rows are not significantly different $(\mathrm{p}>0.01)$

\section{Conclusion}

The present study revealed that strain of broiler chickens did not have significant effect on carcass traits regardless of the treatment imposed on them. This study indicates that any of the strains of broiler chickens can be raised for meat production and revenue generation. However, regardless of strain, fifth week feed restriction recorded higher mean value of live weight and other carcass traits along with birds on control. It is suggested that feed restriction be carried out at younger age for increased meat yield.

\section{ACKNOWLEDGEMENT}

The authors appreciate the staff and management of Ekiti State University Teaching and Research Farm for their support during the course of this study.

\section{REFERENCES}

1. Tumova, A., \& Teimouri, A. (2010). Fat deposition in the broiler chicken: A review. Scientia Agriculturae bonemica, 41(2).

2. Olarenwaju, H. A., Thaxton, J. P., Dizer W. P., Purusel, J., Roush, W. B., \& Branton, S. L. (2006). A review of lighting programme for broiler production. International Journal of Poultry Science, 5(4): 301-308.

3. Jahanpour, H., Seidavi, A., Qothi, A. A., Van Den Hoven, R., Rochae Silva, S., Laudadio, V., \& Tufarelli, V. (2015). Effect of the level and duration of feeding restriction on carcass components of broilers. Arch. Animal Breeding, 58, 99-105.

4. Leeson, S., Yin, F., Yu, H., Lepp, D., Shi, X., Yang, X., Hu, J., Yang, C., Nie, S., \& Hou, Y. (2016). Transcriptome Analysis Reveals Regulation of Gene Expression for lipid catabolism in Young Broilers by Butyrate Glycerides. PloS One, 11(8).

5. Saleh, E. A., Watkins, S. E., Waldroup, A. L., \& Waldroup, P. W. (2004). Comparison of energy feeding programs and early feed restriction on live performance and carcass quality of large broilers grown for further processing at 9 to 12 weeks of age. International Journal of Poultry Science, 3: 61-69. 
6. Zhong, C., Nakane, H. S., Hu, C. Y., \& Mirosh, L. W. (1995). Effect of full feed and early feed restriction on broiler performance, abdominal fat level, cellularity and fat metabolism in broiler chickens. Poultry Science, 74:1636-1643.

7. Houshmand, M., Kamyab, A., Yousefi, K., \& Farshi, A. T. (2003). The performance of broiler chickens during and following different Feed Restriction methods at an early age. Poultry Science, 80: 402-402.

8. [8] Oyedeji, J.O \& Atteh. J.O. (2005). Response of broilers to feeding manipulations. International Journal of Poultry Science, 4(2): 91-95.

9. Fontana, E. A., Weaver, W. D., Watkins, B. A. Jr., \& Denbow, D. M. (1992). Effect of early feed restriction on growth, feed conversion and mortality in broiler chickens. Poultry Science, 71:1296-1305.

10. Azarnik, A., Bojarpour, M., Eslami, M., Ghorbani M. R., \& Mirzadeh, K. (2010). The Effect of different levels of diet protein on broilers performance in ad libitum and feed restriction methods. Journal of Animal and Veterinary Advances, 9(3): 631-634

11. Fasuyi, A., Olawumi, S., Ogunlade, T., Adegun, K., Alamuoye, O., \& Adeusi, A. (2020). Effect of strain and skipa-day feed restriction on carcass characteristics of cocks at $16^{\text {th }}$ week of age. Asian Journal of Advances in Agricultural Research, 12(3): 8-13.

12. Olawumi, S. O., Oyewole, B. O., Okpe, A. A., Amana, C., \& Osagiri, I. (2019). Carcass characteristics and cost benefits of two broiler strains as affected by duration of feed withdrawal at finisher phase. Journal of Scientific Agriculture, 3: 64-67

13. Statistical Analysis System (SAS). (2001). SAS Users Guide. Statistics, $8^{\text {th }}$ edition, SAS Institute Cary, NC, USA.

14. Makram, A., Galal, A., Fathi, M. M., \& El-Attar, A. H. (2010). Carcass characteristics and immunocompetence parameters of four commercial broiler strain chickens under summer season of Egypt. International Journal of Poultry Science, 9(2): 171-176.

15. Chukwuka, O. K., Oscar, O. M. I., Apeh, O., \& Ifeanyi, O. (2010). Effect of strain on growth, carcass characteristics and meat quality of broilers reared for 12 weeks. New York Science Journal, 3(5).

16. Khetani, T. L., Nkukwana, T. T., \& Chimonyo, M. (2009). Effect of quantitative feed restriction on broiler performance. Tropical Animal Health and Production, 41: 379.

17. Olawumi, S. O. (2015). Effects of strain and Feed Restriction at starter phase on performance of Broiler chickens in the Humid Tropics. International Journal of Agricultural Science and Natural Resources, 2(1): 1-5. 